\title{
Analisis Buku Teks Bahasa Indonesia SMP Kelas VIII Terbitan Kemendikbud Edisi Revisi Tahun 2017 (Kesesuaian Isi, Pembentukan Karakter, dan Kompetensi Abad 21)
}

\author{
Analysis of Bahasa Indonesia Textbooks for Eight Grade of Junior High School Published by \\ the Ministry of Education and Culture, Revised Edition of 2017 \\ (Content Suitability, Character Building, and $21^{\text {st }}$ Century Competence) \\ ${ }^{1 *}$ Agus Supriyanto, ${ }^{2}$ Kuntoro \\ ${ }^{1)}$ SMP Negeri 2 Batur Banjarnegara \\ ${ }^{2)}$ Universitas Muhammadiyah Purwokerto \\ *email: agusdean51@gmail.com, kuntorosutaryo@gmail.com
}

\begin{abstract}
Histori Artikel:
Diajukan:

$16 / 03 / 2021$

Diterima:

09/07/2021

Diterbitkan:

12/07/2021
\end{abstract}


Agus Supriyanto, Kuntoro

Analisis Buku Teks Bahasa Indonesia SMP Kelas VIII Terbitan Kemendikbud Edisi Revisi Tahun 2017

(Kesesuaian Isi, Pembentukan Karakter, dan Kompetensi Abad 21)

National Agency of Education Standardization (BSNP), the assessment sheet of character building content, and the assessment sheet of the required competence of the 21st Century. The data collected are displayed descriptively and analyzer using the method of data reduction, data display, conclusion, and verification. Based on the results of the research, it is found out that: 1) the aspect of content compatibility obtains average score of 99.34 with very good quality; 2) the aspect of character building obtains the average score of 92.38 with very good quality; 3) the aspect of compatibility of the content with the required competence of the 21st Century (4Cs) obtains score of 95.83 with the very good quality.

Keywords: Content; Character; Competence of the $21^{\text {st }}$ Century; Textbook

\section{PENDAHULUAN}

Buku teks pelajaran yang baik adalah buku pelajaran yang dapat memantu peserta didik dalam belajar. Buku teks pelajaran bukan hanya merupakan buku yang hanya dibuka atau dibaca pada saat pembelajaran di kelas, melainkan dijadikan sebagai kebutuhan yang dibaca setiap saat.

Buku teks pelajaran dapat dipandang sebagai simpanan pengetahuan tentang segi kehidupan. Karena sudah dipersiapkan dari segi kelengkapan materi dan cara penyajiannya, buku teks pelajaran memberikan fasilitas bagi kegiatan belajar mandiri baik tentang substansi maupun cara penggunaannya.

Sesuai dengan pendekatan saintifik yang digunakan dalam Kurikulum 2013, peserta didik dipacu untuk mencari dari sumber belajar lain yang tersedia dan terbentang luas di sekitarnya. Guru dapat memperkayanya dengan kreasi dalam bentuk kegiatan-kegiatan lain yang sesuai dan relevan yang bersumber dari lingkungan sosial dan alam.

Implementasi Penguatan Pendidikan Karakter (PPK) tidak terlepas dalam pembelajaran baik di luar maupun di dalam kelas. Tercapainya pembelajaran yang berkualitas idealnya menghasilkan sikap yang baik, pengetahuan yang mumpuni dan keterampilan yang terakumulasi pada diri peserta didik.

Keterampilan belajar dan inovasi (Learning and Innovation Skills) merupakan salah satu modal yang sangat penting dalam kecakapan abad 21. Untuk konten/materi pelajaran mungkin akan sangat dinamis dan dapat terus berubah, namun keterampilan tertentu akan terus digunakan dan bermanfaat dalam segala bidang, kondisi, dan masa. Kemampuan ini harus dilatihkan dan dibiasakan hingga menjadi karakter dan budaya dengan mengintegrasikannya ke dalam mata pelajaran. Keterampilan ini sering kali disingkat dengan "4Cs", yang meliputi (1) Creatifity and Innovatian; (2) Critical Thinking and Problem Solving; (3) Communication; dan (4) Collaboration.

Setelah Kurikulum 2013 diberlakukan oleh pemerintah, buku teks Bahasa Indonesia SMP kelas VIII terbitan Kemendikbud edisi revisi tahun 2017 merupakan buku wajib yang digunakan sebagai sumber pembelajaran disekolah. Sebagai buku wajib, tentunya perlu diketahui apakah buku tersebut sudah sesuai dengan tuntutan kurikulum 2013 atau belum. Dan untuk mengetahui hal tersebut, perlu diadakan analisis terhadap kelayakan buku tersebut. Atas dasar hal tersebut, peneliti akan menganalisis buku teks dengan judul: "Analisis Buku Teks Bahasa Indonesia Kelas VIII Terbitan Kemendikbud Edisi Revisi Tahun 2017 (Kesesuaian Isi, Pembentukan Karakter, dan Kompetensi Abad 21).

\section{Rumusan Masalah}

Rumusan masalah dalam penelitian ini adalah: 1) Bagaimana kesesuaian isi buku teks Bahasa Indonesia SMP kelas VIII terbitan Kemendikbud edisi revisi tahun 2017?; 2) Bagaimana kesesuaian pembentukan karakter buku teks Bahasa Indonesia SMP kelas VIII terbitan Kemendikbud edisi revisi tahun 2017?; 3) Bagaimana kesesuaian Kompetensi Abad 21 (4Cs) dalam buku teks Bahasa Indonesia SMP kelas VIII terbitan Kemendikbud edisi revisi tahun 2017? 
Agus Supriyanto, Kuntoro

Analisis Buku Teks Bahasa Indonesia SMP Kelas VIII Terbitan Kemendikbud Edisi Revisi Tahun 2017

(Kesesuaian Isi, Pembentukan Karakter, dan Kompetensi Abad 21)

\section{Landasan Teori \\ Buku Teks}

Peraturan Menteri Pendidikan Nasional

Nomor 11 Tahun 2005 menjelaskan bahwa buku teks adalah buku acuan wajib untuk digunakan di sekolah yang memuat materi pembelajaran dalam rangka meningkatkan keimanan dan ketakwaan, budi pekerti dan kepribadian, kemampuan penguasaan ilmu pengetahuan dan teknologi, kepekaan dan kemampuan estetis, serta potensi fisik dan kesehatan yang disusun berdasar standar nasional pendidikan.

\section{Jenis-Jenis Buku Teks}

Secara khusus Prastowo (2014:168) mengemukakan secara umum ada dua jenis buku teks yaitu sebagai buku teks utama dan buku teks pelengkap. Buku teks utama adalah buku yang berisi bahan-bahan pelajaran suatu bidang studi yang digunakan sebagai buku pokok bagi pendidik dan peserta didik, sedangkan buku teks pelengkap adalah buku yang sifatnya memantu atau sebagai buku tambahan yang digunakan pendidik dan peserta didik.

\section{Keunggulan Buku Teks bagi Kegiatan Pembelajaran}

Nasution dalam Prastowo (2014:171) mengemukakan tujuh keunggulan buku teks sebagai berikut: 1) Membantu pendidik dalam melaksanakan kurikulum karena disusun berdasarkan kurikulum yang berlaku; 2) Menjadi pegangan guru dalam menentukan metode pembelajaran; 3) Memberi kesempatan peserta didik untuk mengulangi pelajaran atau mempelajari pelajaran baru; 4) Dapat digunakan untuk tahun-tahun berikutnya, dan jika direvisi maka dapat bertahan dalam waktu yang lama; 5) Memberi kesamaan mengenai bahan dan standar pengajaran; 6) Memberi kontinuitas pelajaran di kelas yang berurutan sekalipun pendidik berganti-ganti; 7) Memberi pengetahuan dan metode mengajar yang lebih mantap jika guru menggunakan dari tahun ke tahun.

\section{Kelemahan Buku Teks}

Muslich (2010:30) menjelaskan kelemahan-kelemahan buku teks sebagai berikut: a) Buku teks kurang memperhatikan perbedaan individu peserta didik. Peserta didik sasaran dianggap homogen sehingga bahan ajar yang ada pada buku teks tersaji tanpa memperhatikan peserta didik yang uper (unggul) dan peserta didik yang lower; b) Desain buku teks sering tidak sesuai dengan desain kurikulum pendidikan. Akibatnya, dengan menggunakan buku teks tersebut, program pendidikan yang telah dirancang dalam kurikulum tidak tercapai; c) Konteks dan bahan ajar yang terdapat dalam buku teks sering tidak sesuai dengan kondisi dan lingkungan peserta didik sasaran. Apabila hal ini terjadi, buku teks akan terkesan memaksa peserta didik untuk belajar sesuatu yang tidak sesuai dengan kondisi dirinya; d) Bahan ajar yang terdapat dalam buku teks sering bias dan basi. Ini terjadi karena antara waktu penyusunan buku teks dan waktu pemakaiannya berselang terlalu lama. Akibatnya, informasi dan masalah yang terdapat dalam buku teks sudah kedaluwarsa, bahkan tidak sesuai lagi dengan yang sedang dihadapi peserta didik.

\section{Peranan Buku Teks}

Tarigan dan Tarigan (2009: 17) menjelaskan peranan buku teks di antaranya sebagai berikut: a) Mencerminkan suatu sudut pandangan yang tangguh dan modern mengenai pengajaran serta mendemonstrasikan aplikasinya dalam pengajaran yang disajikan; b) Menyajikan suatu sumber pokok masalah atau subject matter yang kaya, mudah dibaca atau bervariasi, yang sesuai dengan minat dan kebutuhan peserta didik, sebagai dasar bagi program-program kegiatan yang disarankan di mana keterampilan-keterampilan ekspresional diperoleh di bawah kondisi-kondisi yang mempunyai kehidupan yang sebenarnya; c) Menyediakan suatu sumber yang tersusun rapi dan bertahap mengenai keterampilanketerampilan ekspresional yang mengemban masalah pokok dalam komunikasi; d) Menyajikan bersama-sama dengan buku manual pendampingnya, metode-metode, dan sarana-sarana pengajaran untuk memotivasi para peserta didik; e) Menyajikan fikasi (perasaan yang mendalam) awal yang perlu 
dan juga sebagai penunjang bagi latihanlatihan dan tugas-tugas praktis; f) Menyajikan bahan/sarana evaluasi dan remidial yang serasi dan tepat guna.

\section{Kriteria Buku Teks yang Baik dan Berkualitas \\ Schorling dan Batchelder dalam} Muslich (2010:54) memberikan empat ciri buku teks yang baik sebagai berikut: a) Direkomendasi oleh guru-guru yang berpengalaman sebagai buku teks yang baik; b) Bahan ajarnya sesuai dengan tujuan pendidikan, kebutuhan peserta didik, dan kebutuhan masyarakat; c) Cukup banyak memuat teks bacaan, bahan drill dan latihan/tugas; d) Memuat ilustrasi yang membantu peserta didik belajar.

\section{Analisis Buku Teks}

Menurut Komaruddin (2002: 43) analisis adalah kegiatan berpikir untuk menguraikan suatu keseluruhan menjadi komponen sehingga dapat mengenal tandatanda komponen, hubungan satu sama lain dan fungsi masing-masing dalam satu keseluruhan yang terpadu. Menurut Gorys Keraf, Analisa adalah seuah proses untuk memecahkan sesuatu ke dalam bagian-bagian yang saling berkaitan satu sama lain (2019.www.http: //pe ngertiandefinisi.com, diakses pada 28 Desember 2019 pukul 20.00).

\section{Kualitas Buku Teks}

Tarigan dan Tarigan (2009: 24) mengungkapkan bahwa ilmu pengetahuan dapat dihimpun ke dalam suatu wadah yang selalu tersedia secara permanen dengan pertolingan buku-buku. Buku teks memberi kesempatan pada pemiliknya untuk menyegarkan kembali ingatan. Bahkan pembacaaan kembali dapat pula dipakai sebagai pemeriksaan daya ingat seseorang terhadap hal yang pernah dipelajarinya melalui buku teks. Sarana khusus yang ada dalam suatu buku teks dapat menolong para pembaca untuk memahami isi buku. Sarana seperti skema, diagram, matriks, gambar-gambar ilustrasi, dan sebagainya, berguna sekali dalam mengantar pembaca ke arah pemahaman isi buku.
Isi Materi Buku Teks dan Kurikulum 2013

Kurikulum dikembangkan atas dasar teori pendidikan berdasarkan standar dan teori pendidikan berasis kompetensi. Pendidikan berbasis standar adalah pendidikan yang menetapkan standar nasional seagai kualitas minimal hasil belajar yang berlaku untuk setiap kurikulum. Kualitas standar nasional dinyatakan sebagai Standar Kompetensi Lulusan. Standar Kompetensi Lulusan tersebut adalah kualitas minimal lulusan suatu jenjang atau satuan pendidikan. Standar Kompetensi Lulusan mencakup sikap, pengetahuan, dan keterampilan (PP Nomor 19 Tahun 2005). Standar Kompetensi Lulusan dikembangkan menjadi Standar Kompetensi Lulusan Satuan Pendidikan yaitu SKL SD, SMP, SMA, SMK. Standar Kompetensi Lulusan Satuan Pendidikan berisikan 3 (tiga) komponen yaitu kemampuan proses, konten, dan ruang lingkup penerapan komponen proses dan konten. Komponen proses adalah kemampuan minimal untuk mengkaji dan memproses konten menjadi kompetensi. Komponen konten adalah dimensi kemampuan yang menjadi sosok manusia yang dihasilkan dari pendidikan. Komponen ruang lingkup adalah keluasan lingkungan minimal di mana kompetensi terseut digunakan, dan menunjukkan gradasi antara satu satuan pendidikan dengan satuan pendidikan di atasnya serta jalur satuan pendidikan khusus (SMK, SDLB, SMPLB, SMALB).

\section{Alasan Pengembangan Kurikulum 2013}

Alasan pengemangan Kurikulum 2013 ada empat hal: 1) Fenomena yang mengemuka di masyarakat seperti adanya perkelahian pelajar, narkoba, korupsi, plagiarism, kecurangan UN, dan adanya gejolak dalam masyarakat; 2) Persepsi masyarakat terhadap kurikulum seperti terlalu menitikberatkan pada aspek kognitif; 3) Kompetensi masa depan seperti kemampuan berkomunikasi, kemampuan berpikir jernih dan kritis, kemampuan mempertimbangkan dari segi oral suatu permasalahan, kemampuan menjadi warga negara yang bertanggung jawab, kemampuan mencoba, mengerti dan toleran terhadap pandangan yang berbeda, kemampuan hidup dalam masyarakat yang 
mengglobal, memiliki beban siswa yang terlalu berat, dan kurang bermuatan karakter, minat luas dalam kehidupan, memiliki kesiapan untuk bekerja, memiliki kecerdasan sesuai bakat dan minatnya dan memiliki tanggung jawab terhadap lingkungan; 4) Tantangan masa depan seperti globalisasi, masalah lingkungan hidup, kemajuan iptek, konvergensi ilmu pengetahuan dan teknologi, ekonomi berbasis pengetahuan, kebangkitan industri kreatif dan budaya, pergeseran kekuatan ekonomi dunia, pengaruh dan imbas teknosains, tuntutan mutu, investasi dan transformasi pada sektor pendidikan dan hasilhasil pengukuran TIMMS dan PISA.

\section{Karakteristik Kurikulum 2013}

Karakteristik kurikulum 2013 meliputi: 1) Isi atau konten kurikulum adalah kompetensi yang dinyatakan dalam bentuk Kompetensi Inti (KI) mata pelajaran dan dirinci lebih lanjut ke dalam Kompetensi Dasar (KD); 2) Kompetensi Inti (KI) merupakan gambaran secara kategorial mengenai kompetensi yang harus dipelajari peserta didik untuk suatu jenjang sekolah, kelas, dan mata pelajaran; 3) Kompetensi Dasar (KD) merupakan kompetensi yang dipelajari peserta didik untuk suatu mata pelajaran di kelas tertentu; 4) Penekanan kompetensi ranah sikap, keterampilan kognitif, keterampilan psikomotorik, dan pengetahuan untuk suatu satuan pendidikan dan mata pelajaran ditandai oleh banyaknya KD suatu mata pelajaran. Untuk SD pengembangan sikap menjadi kepedulian utama kurikulum; 5) Kompetensi Inti menjadi unsur oragisatoris kompetensi bukan konsep, generalisasi, topik atau suatu yang erasal dari pendekatan "disciplinary-based curriculum" atau "contentbased curriculum"; 6) Kompetensi Dasar (KD) yang dikembangkan didasarkan pada prinsip akumulatif, saling memperkuat dan memperkaya antarmata pelajaran; 7) Proses pembelajaran didasarkan pada upaya menguasai kompetensi pada tingkat yang memuaskan dengan memperhatikan karakteristik konten kompetendi di mana pengetahuan adalah konten yang bersifat tuntas (mastery). Keterampilan kognitif dan psikomotorik adalah kemampuan penguasaan konten yang dapat dilatihkan. Sedangkan sikap adalah kemampuan penguasaan konten yang lebih sulit dikembangkan dan memerlukan proses pendidikan yang tidak langsung; 8) Penilaian hasil belajar mencakup seluruh aspek kompetensi, bersifat formatif dan hasilnya segera diikuti dengan pembelajaran remedial untuk memastikan penguasaan kompetensi pada tingkat memuaskan (Kriteria Ketuntasan Minimal/KKM dapat dijadikan tingkat memuaskan).

\section{Keberadaan Mata Pelajaran Bahasa Indonesia dalam Kurikulum 2013}

Keberadaan bahasa Indonesia tidak hanya dipertahankan berada dalam daftar pelajaran di sekolah, tetapi juga menegaskan pentingnya keberadaan bahasa Indonesia sebagai penghela dan pembawa ilmu pengetahuan. Perubahan pembelajaran dari KTSP yang menekankan segi keterampilan berbahasa ke kurikulum baru yaitu Kurikulum 2013 yang menekankan pembelajaran berbasis teks.

Pembelajaran bahasa Indonesia berbasis teks dilaksanakan dengan menerapkan prinsip bahwa (1) bahasa hendaknya dipandang sebagai teks, bukan semata-mata kumpulan kata-kata atau kaidah kebahasaan; (2) penggunaan bahasa merupakan proses pemilihan bentuk kebahasaan untuk mengungkapkan makna; (3) bahasa bersifat fungsional, yaitu penggunaan bahasa yang tidak pernah dapat dilepaskan dari konteks karena bentuk bahasa yang digunakan itu mencerminkan ide, sikap, nilai, dan ideologi penggunanya; dan (4) bahasa merupakan sarana pembentukan kemampuan berpikir manusia.

Buku siswa yang disediakan oleh pemerintah dalam Kurikulum 2013 menjabarkan usaha minimal yang harus dilakukan peserta didik untuk mrncapai kompetensi yang diharapkan. Sedangkan dalam proses belajar, peserta didik dipacu untuk mencari dari sumber belajar lain yang terbentang luas dan tersedia disekitarnya. Peran guru menjadi sangat penting dalam meningkatkan dan menyesuaikan daya serap peserta didik dengan ketersediaan kegiatan pada buku tersebut. Guru diharapkan dapat 
memperkaya dengan kreasi dalam bentuk kegiatn-kegiatan lain yang sesuai dan relevan yang bersumber dari lingkungan sosial dan alam daerah masing-masing.

\section{Amanat Kurikulum $2013 \quad$ Melalui Pendekatan Saintifik \\ Dalam Ariyana, dkk. (2019: 19)} dinyatakan bahwa proses pembelajaran dapat dipadankan dengan suatu proses ilmiah, karena itu Kurikulum 2013 mengamanatkan esensi pendekatan saintifik dalam pembelajaran. Pendekatan saintifik diyakini sebagai titian emas perkembangan sikap, pengetahuan, dan keterampilan peserta didik. Dalam pendekatan atau proses kerja yang memenuhi kriteria ilmiah, para ilmuwan lebih mengedepankan penalaran induktif (inductive reasoning) yang memandang fenomena atau situasi spesifik untuk kemudian menarik simpulan secara keseluruhan. Metode ilmiah merujuk pada teknik-teknik investigasi atau suatu venomena/ gejala, memperoleh pengetahuan baru, atau mengoreksi dan memadukan pengetahuan sebelumnya.

Proses pembelajaran saintifik memuat aktivitas (a) mengamati; (b) menanya; (c) mengumpulkan informasi/mencoba; (d) mengasosiasikan/ mengolah informasi; dan (e) mengomunikasikan.

\section{Aspek-Aspek Isi Materi Buku Teks}

Pusat Perbukuan Depdiknas (2005: 11) menyebutkan beberapa aspek kesesuaian isi materi, dengan sub aspek beserta indikator masing-masing yang harus diperhatikan. Dari aspek pada materi di antaranya adalah 1) kelengkapan materi, 2) keruntutan, 3) koneksi (keterkaitan), 4) menggunakan gambar, tabel, cerita, grafik, atau ilustrasi.

\section{Penguatan Pendidikan Karakter}

Peraturan Presiden Nomor 87 Tahun 2017 tentang Penguatan Pendidikan Karakter hadir dengan pertimbangan bahwa dalam mewujudkan bangsa yang berbudaya melalui penguatan nilai-nilai religius, jujur, toleran, disiplin, bekerja keras, kreatif, mandiri, demokratis, rasa ingin tahu, semangat kebangsaan, cinta tanah air, menghargai prestasi, komunikatif, cinta damai, gemar membaca, peduli lingkungan, peduli sosial, dan bertanggung jawab, pemerintah memandang perlu penguatan pendidikan karakter.

\section{Nilai-Nilai Utama Pendidikan Karakter}

Gerakan Penguatan Pendidikan Karakter (PPK) merupakan bagian integral Nawacita, dalam hal ini 8 butir Nawacita: Revolusi Karakter Bangsa dan Gerakan Revolusi Mental dalam pendidikan yang hendak mendorong seluruh pemangku kepentingan untuk mengadakan perubahan paradigma, yaitu perubahan pola pikir dan cara bertindak dalam mengelola sekolah. Dalam Hendarman, dkk. (2016: 7) dikatakan ada 5 nilai utama karakter yang saling berkaitan membentuk jejaring nilai karakter yang perlu dikembangkan sebagai prioritas Gerakan PPK. Kelima nilai utama karakter bangsa yang dimaksud adalah: 1) rekigius; 2) nasionalis; 3) mandiri; 4) gotong royong; dan 5) integritas.

\section{Pembelajaran Abad 21}

Pembelajaran abad 21 kita dihadapkan dengan fenomena yang ada di lingkungan sekitar kita, seperti informasi yang selalu up to date. Informasi yang beredar di sekeliling kita, kita mengetahuinya dari berbagai alat-alat canggih yang diciptakan karena kemajuan teknologi. Pernahkah kita membayangkan jika kita tidak mengalami perubahan dan bahkan selalu sama? Rasanya hampir tidak pernah, kita lupa pada hal-hal kecil yang membuat kita tegak berdiri seperti sekarang ini. Kehidupan yang serba cepat, membuat kita dituntut untuk berpikir out of the box (Satrianawati, 2017: 1).

\section{Kompetensi Keterampilan 4Cs (Creativity, Critical Thinking, Collaboration, Communication)}

Pembelajaran abad 21 menggunakan istilah yang dikenal sebagai "4Cs" (creativity, critical thinking, collaboration, communication). 4Cs adalah empat keterampilan yang telah diidentifikasi sebagai keterampilan abad ke-21 (P21) yaitu keterampilan yang sangat penting dan diperlukan untuk pendidikan abad ke-21 (Ariyana, dkk., 2019: 16). 
Agus Supriyanto, Kuntoro

Analisis Buku Teks Bahasa Indonesia SMP Kelas VIII Terbitan Kemendikbud Edisi Revisi Tahun 2017

(Kesesuaian Isi, Pembentukan Karakter, dan Kompetensi Abad 21)

\begin{tabular}{|c|c|}
\hline $\begin{array}{l}\text { FRAMEWORK } \\
21^{s t} \\
\text { CENTURY } \\
\text { SKILLS }\end{array}$ & $\begin{array}{l}\text { KOMPETENSI } \\
\text { BERPIKIR P21 }\end{array}$ \\
\hline $\begin{array}{l}\text { Ceativity } \\
\text { Thinking and } \\
\text { Innovation }\end{array}$ & $\begin{array}{l}\text { Peserta didik dapat } \\
\text { menghasilkan, mengem- } \\
\text { bangkan, dan } \\
\text { mengimplementasikan } \\
\text { ide-ide mereka secara } \\
\text { kreatif baik secara man- } \\
\text { diri maupun berke- } \\
\text { lompok. }\end{array}$ \\
\hline $\begin{array}{l}\text { Critical Thinking } \\
\text { and Problem } \\
\text { Solving }\end{array}$ & $\begin{array}{l}\text { Peserta didik dapat } \\
\text { mengidentifikasi, } \\
\text { menganalisis, } \\
\text { enginterpretasikan, dan } \\
\text { mengevaluasi bukti-bukti, } \\
\text { argumentasi, klaim, dan } \\
\text { data-data yang tersaji } \\
\text { secara luas melalui } \\
\text { pengkajian secara } \\
\text { mendalam, serta } \\
\text { merefleksikannya dalam } \\
\text { kehidupan sehari-hari. }\end{array}$ \\
\hline Communication & $\begin{array}{l}\text { Peserta didik dapat } \\
\text { mengomunikasikan ide- } \\
\text { ide dan gagasan secara } \\
\text { efektif menggunakan } \\
\text { media lisan, tertulis, } \\
\text { maupun teknologi. }\end{array}$ \\
\hline Collaboration & $\begin{array}{ll}\text { Peserta didik } & \text { dapat } \\
\text { bekerja sama } & \text { salam } \\
\text { sebuah kelompok } & \text { dalam } \\
\text { memecahkan } & \\
\text { permasalahan } & \text { yang } \\
\text { ditemukan. } & \end{array}$ \\
\hline
\end{tabular}

(Ariyana, dkk., 2019: 16)

\section{Kerangka Konsep Berpikir Abad 21 di Indonesia}

Dalam Ariyana, dkk. (2019: 17) dinyatakan bahwa implementasi dalam merumuskan kerangka sesuai P21 bersifat mutidisiplin, artinya semua materi dapat didasarkan sesuai kerangka P21. Untuk melengkapi kerangka P21 sesuai tuntutan pendidikan di Indonesia, berdasarkan hasil kajian dokumen pada UU Sisdiknas, Nawacita, dan RPJMN Pendidikan Dasar, Menengah, dan Tinggi, diperoleh dua standar tambahan sesuai dengan kebijakan kurikulum dan kebijakan pemerintah, yaitu sesuai dengan Penguatan Pendidikan Karakter (Character Building) dan Nilai Spiritual (Spiritual Value). Secara keseluruhan standar P21 di Indonesia ini dirumuskan menjadi Indonesian Partnership for 21 Century Skill Standard (IP21CSS).

\section{METODE}

\section{Tempat dan Waktu Penelitian}

Penelitian ini dilaksanakan selama dua bulan mulai bulan Desember 2019 sampai dengan Januari 2020 di Kabupaten Banjarnegara. Penelitian ini akan dilakukan di mana saja yaitu untuk merekam atau mengambil semua teori, data, dan segala hal yang berhubungan serta mendukung penelitian ini di manapun dan kapanpun.

\section{Metode Penelitian}

Penelitian ini merupakan penelitian kualitatif, sedangkan metode yang digunakan adalah metode content analisys atau kajian isi. Guba dan Lincoln dalam Moleong (2007: 220) mengemukakan bahwa kajian isi adalah teknik apapun yang digunakan untuk menarik kesimpulan melalui usaha menemukan karakteristik pesan dan dilakukan secara objektif dan sistematis. Data-data yang dianalisis tidak untuk menerima atau menolak hipotesis (jika ada), melainkan hasil analisis itu berupa deskripsi dari gejala-gejala yang diamati, yang tidak harus berupa angka-angka atau koefesien antarvariabel. Penelitian ini berusaha untuk melaporkan keadaan objek yang diteliti untuk menjawab permasalahan penelitian. Data-data tersebut sudah ada pada objek penelitian yaitu buku teks Bahasa Indonesia SMP kelas VIII terbitan Kemendikbud edisi revisi tahun 2017 yang kemudian dianalisis dari segi isi, pembentukan karakter, dan Kompetensi Abad 21 (4Cs).

\section{Sumber Data}

Data penelitian diperoleh dari buku teks Bahasa Indonesia SMP kelas VIII yang dikeluarkan pemerintah berdasarkan Kurikulum 2013. Buku tersebut diterbitkan oleh Kementerian Pendidikan dan Kebudayaan 
Republik Indonesia cetakan ke-2 tahun 2017 (edisi revisi).

Analisis data buku teks Bahasa Indonesia berdasarkan standar BNSP dilakukan dengan lembar penilaian buku teks yang dibuat dengan memperhatikan aspek isi, pembentukan karakter, dan Kompetensi Abad 21 (4Cs).

\section{Teknik Pengumpulan Data}

Arikunto (2006: 126) mengatakan bahwa metode pengumpulan data adalah metode yang digunakan oleh peneliti dalam mengumpulkan data penelitiannya. Metode pengumpulan data yang digunakan dalam penelitian ini adalah metode dokumentasi. Metode dokumentasi digunakan untuk memperoleh data persentase skor pada tiaptiap subaspek yang diteliti. Dokumentasi dilakukan dengan memberikan skor tiap-tiap indikator untuk masing-masing bab pada lembar penilaian. Kriteria skor yang digunakan untuk memberikan penilaian telah ditetapkan oleh BSNP.

Selanjutnya Sugiyono (2014: 198) mengatakan ahwa instrumen penelitian adalah suatu alat yang digunakan untuk mengukur fenomena alam maupun sosial yang diamati. Instrumen penelitian yang digunakan dalam penelitian ini adalah lembar penilaian, yaitu instrumen penilaian isi buku teks Bahasa Indonesia menurut BSNP, instrumen penilaian pembentukan karakter, dan instrumen penilaian Kompetensi Abad 21 (4Cs).

\section{Teknik Analisis Data}

Sugiyono (2014: 333) mengemukakan bahwa data yang terkumpul dalam penelitian kualitatif menggunakan teknik triangulasi yang bersifat menggabungkan dari berbagai teknik pengumpulan data dan sumber data yang telah ada. Pengambilan data dilakukan secara terusmenerus sampai datanya jenuh karena dengan pengamatan yang terus-menerus mengakibatkan variasi data tinggi sekali.

Dalam penelitian ini, data yang diperoleh dituangkan dalam bentuk tulisan dan dianalisis dengan cara berikut: 1) Reduksi Data; 2) Display Data; dan 3) Mengambil Kesimpulan dan Verifikasi. Data collection merupakan semua data yang akan diteliti.
Kemudian data direduksi, yaitu memilih halhal yang pokok, memfokuskan pada hal-hal yang penting. Tahap berikutnya display data yaitu menyajikan data dalam bentuk uraian ataupun bagan. Selanjutnya Conclusion drawing and verifying yaitu penarikan kesimpulan dan verifikasi. Simpulan didukung dengan bukti yang valid dan konsisten, maka simpulan yang dikemukakan merupakan kesimpulan yang kredibel.

Pengukuran Variabel Penskoran Aspek Isi, Pembentukan Karakter, dan Kompetensi Abad 21 (4Cs)

Menurut Pusat Perbukuan Depdiknas (2005: 30), nilai dari tiap indikator-indikator ditentukan sebagai berikut: Skor 7: Jika makna dari semua kata kunci dalam suatu indi-kator ditemukan dan penilai memperlihatkan (nomor hal buku) indikator yang dimaksud. Skor 5: Jika lebih dari 50\% dari makna kata-kata kunci ditemukan dan penilai mengusulkan saran untuk perbaikan. Skor 3: Jika kurang dari 50\% dari makna kata-kata kunci ditemukan dan penilai mengusulkan saran untuk perbaikan. Skor 1: Jika dari semua makna kata kunci tidak ditemukan dan penilai dapat mengusulkan suatu perbaikan.

Setelah diperoleh skor pada setiap indikator subaspek, selanjutnya persentase skor setiap subaspek dihitung dengan rumus sebagai berikut:

Jumlah skor yang diperolah tiap subaspek P = -------------------- X100 Jumlah skor maksimal tiap subaspek

\section{Kriteria Kualitas Buku Teks}

Kriteria kualitas buku untuk standar aspek kelayakan isi, pembentukan karakter, dan Kompetensi Abad 21 (4Cs) ditetapkan dalam tabel sebagai berikut.

\begin{tabular}{|l|l|}
\hline Persentase (\%) & Kualitas \\
\hline $85-100$ & Sangat Baik \\
\hline $65-84$ & Baik \\
\hline $55-64$ & Cukup Baik \\
\hline $40-54$ & Kurang Baik \\
\hline $0-39$ & Tidak Baik \\
\hline
\end{tabular}

(Farisi, 2012: 598) 
Agus Supriyanto, Kuntoro

Analisis Buku Teks Bahasa Indonesia SMP Kelas VIII Terbitan Kemendikbud Edisi Revisi Tahun 2017

(Kesesuaian Isi, Pembentukan Karakter, dan Kompetensi Abad 21)

\section{Uji Validasi Hasil Analisis}

Untuk menguji keabsahan data diperlukan teknik pemeriksaan. Pelaksanaan teknik pemeriksaan didasarkan atas sejumlah kriteria tertentu. Ada empat kriteria yang digunakan, yaitu derajat kepercayaan (creadibility), keteralihan (transferability), kebergantungan (dependability), dan kepastian (confirmability).

\section{HASIL DAN PEMBAHASAN}

\section{Deskripsi Data}

Objek penelitian ini adalah buku teks Bahasa Indonesia SMP kelas VIII terbitan Depdikbud edisi revisi tahun 2017 berjudul "Bahasa Indonesia SMP/MTs Kelas VIII". Buku teks ini berlaku untuk dua semester, terdiri atas sembilan bab.

\section{Pembahasan Hasil Penelitian}

Penelitian ini dilakukan dengan cara menganalisis buku teks Bahasa Indonesia SMP kelas VIII terbitan Depdikbud edisi revisi tahun 2017 dengan tahapan-tahapan. Tahap pertama yaitu menganalisis dari segi kesesuaian isi berdasarkan standar BSNP. Tahap kedua yaitu menganalisis kesesuaian pembentukan karakter. Tahap ketiga yaitu menganalisis kesesuaian Kompetensi Abad 21 (4Cs).

\section{Perolehan Skor Aspek Kesesuaian Isi}

Subaspek pertama yaitu kelengkapan materi, memperoleh skor sebesar 98,94 dengan tingkat kualitas Sangat Baik. Subaspek kedua yaitu keruntutan materi memperoleh skor $\mathbf{1 0 0}$ dengan tingkat kualitas Sangat Baik. Subaspek ketiga yaitu materi memunculkan aspek keterkaitan (connection), memperoleh skor 98,41 dengan tingkat kualitas Sangat Baik. Subaspek keempat yaitu penyajian konsep dilengkapi dengan gambar, tabel, skema, atau ilustrasi, memperoleh skor $\mathbf{1 0 0}$ dengan tingkat kualitas Sangat Baik. Skor rata-rata keseluruhan sebesar 99,34 dengan tingkat kualitas Sangat Baik. Lebih jelasnya rincian perolehan skor aspek kesesuaian isi tersebut dapat dilihat pada tabel 4.1 berikut ini:
Tabel 4.1 Perolehan Persentase Skor Aspek Kesesuaian Isi

\begin{tabular}{|l|l|l|l|}
\hline No. & Subaspek & Skor & Kualitas \\
\hline 1. & $\begin{array}{l}\text { Kelengkapan } \\
\text { materi }\end{array}$ & 98,94 & $\begin{array}{l}\text { Sangat } \\
\text { Baik }\end{array}$ \\
\hline 2. & $\begin{array}{l}\text { Keruntutan } \\
\text { materi }\end{array}$ & 100 & $\begin{array}{l}\text { Sangat } \\
\text { Baik }\end{array}$ \\
\hline 3. & $\begin{array}{l}\text { Materi } \\
\text { memunculkan } \\
\text { aspek keterkaitan }\end{array}$ & $\begin{array}{l}\text { Penyajian konsep } \\
\text { dilengkapi } \\
\text { dengan gambar, } \\
\text { tabel, skema, } \\
\text { atau ilustrasi }\end{array}$ & $\begin{array}{l}\text { Sangat } \\
\text { Baik }\end{array}$ \\
\hline & 100 & $\begin{array}{l}\text { Sangat } \\
\text { Baik }\end{array}$ \\
\hline Rata-rata & 99,34 & $\begin{array}{l}\text { Sangat } \\
\text { Baik }\end{array}$ \\
\hline
\end{tabular}

\section{Perolehan Skor Aspek Kesesuaian Pembentukan Karakter}

Aspek kesesuaian pembentukan karakter terdiri atas lima aspek karakter yaitu: (1) religius; (2) nasionalisme; (3) kemandirian; (4) gotong-royong; dan (5) integritas (Hendarman, dkk., 2016: 7).

Aspek karakter pertama yaitu religius, memperoleh skor 93,65 dengan tingkat kualitas Sangat Baik. Aspek karakter kedua yaitu nasionalisme, memperoleh skor $\mathbf{8 0 , 9 5}$ dengan tingkat kualitas Baik. Aspek karakter ketiga yaitu kemandirian, memperoleh skor 93,65 dengan tingkat kualitas Sangat Baik. Adapun aspek karakter kelima yaitu integritas, memperoleh skor $\mathbf{9 6 , 8 3}$ dengan tingkat kualitas Sangat Baik. Skor rata-rata keseluruhan seesar 92,38 dengan tingkat kualitas Sangat Baik. Lebih jelasnya rincian perolehan skor aspek kesesuian pembentukan karakter dapat dilihat pada tabel 4.2 berikut ini: 
Agus Supriyanto, Kuntoro

Analisis Buku Teks Bahasa Indonesia SMP Kelas VIII Terbitan Kemendikbud Edisi Revisi Tahun 2017

(Kesesuaian Isi, Pembentukan Karakter, dan Kompetensi Abad 21)

Tabel 4.2 Perolehan Persentase Skor

Aspek Kesesuaian Pembentukan Karakter

\begin{tabular}{|l|l|l|l|}
\hline No. & Nilai Karakter & Skor & Kualitas \\
\hline 1. & Religius & 93,65 & $\begin{array}{l}\text { Sangat } \\
\text { Baik }\end{array}$ \\
\hline 2. & Nasionalisme & 80,95 & Baik \\
\hline 3. & Kemandirian & 93,65 & $\begin{array}{l}\text { Sangat } \\
\text { Baik }\end{array}$ \\
\hline 4. & $\begin{array}{l}\text { Gotong } \\
\text { Royong }\end{array}$ & 96,83 & $\begin{array}{l}\text { Sangat } \\
\text { Baik }\end{array}$ \\
\hline 5. & Integritas & 96,83 & $\begin{array}{l}\text { Sangat } \\
\text { Baik }\end{array}$ \\
\hline & Rata-rata & 92,38 & $\begin{array}{l}\text { Sangat } \\
\text { Baik }\end{array}$ \\
\hline
\end{tabular}

\section{Perolehan Skor Aspek Kesesuaian Kompetensi Abad 21 (4Cs)}

Aspek kesesuaian Kompetensi Abad 21

(4Cs) terdiri atas empat kompetensi yaitu: (1) Creatifity Thinking and Innovation atau berpikir kreatif dan inovasi; (2) Critical Thinking and Problem Solving atau penalaran efektif dan memecahkan masalah; (3) Communication atau ko-munikasi; dan (4) Collaboration atau kolaborasi (Ariyana, dkk., 2019: 16).

Aspek kesesuaian Kompetensi Abad 21 (4Cs) yang pertama yaitu Creatifity Thinking and Innovation atau berpikir kreatif dan inovasi, memperoleh skor 96,83 dengan tingkat kualitas Sangat Baik. Aspek 4Cs kedua yaitu Critical Thinking and Problem Solving atau penalaran efektif dan memecahkan masalah, memperoleh skor 99,21 dengan tingkat kualitas Sangat Baik. Aspek 4Cs ketiga yaitu Communication atau komunikasi, memperoleh skor 93,65 dengan tingkat kualitas Sangat Baik. Dan aspek 4Cs yang keempat yaitu Collaboration atau kolaborasi, memperoleh skor 93,65 dengan tingkat kualitas Sangat Baik. Skor rata-rata keseluruhan sebesar 92,38 dengan tingkat kualitas Sangat Baik. Lebih jelasnya rincian perolehan skor aspek kesesuian Kompetensi Abad 21 (4Cs) dapat dilihat pada tabel 4.3 berikut ini:
Tabel 4.3 Perolehan Persentase Skor Aspek Kesesuaian Kompetensi Abad 21 (4Cs)

\begin{tabular}{|l|l|l|l|}
\hline No. & $\begin{array}{l}\text { 4Cs (Century } \\
\text { Skills) }\end{array}$ & Skor & Kualitas \\
\hline 1. & $\begin{array}{l}\text { Creatifity } \\
\text { Thinking and } \\
\text { Innovation }\end{array}$ & 96,83 & $\begin{array}{l}\text { Sangat } \\
\text { Baik }\end{array}$ \\
\hline 2. & $\begin{array}{l}\text { Critical Thinking } \\
\text { and Problem } \\
\text { Solving }\end{array}$ & 99,21 & $\begin{array}{l}\text { Sangat } \\
\text { Baik }\end{array}$ \\
\hline 3. & Communication & 93,65 & $\begin{array}{l}\text { Sangat } \\
\text { Baik }\end{array}$ \\
\hline 4. & Collaboration & 93,65 & $\begin{array}{l}\text { Sangat } \\
\text { Baik }\end{array}$ \\
\hline & Rata-rata & 95,83 & $\begin{array}{l}\text { Sangat } \\
\text { Baik }\end{array}$ \\
\hline
\end{tabular}

\section{Pembahasan}

Berikut ini akan dibahas beberapa temuan terkait dengan aspek-aspek yang dianalisis yaitu kesesuaian mataeri, kesesuaian pembentukan karakter, dan kesesuaian Kompetensi Abad 21 (4Cs).

\section{Aspek Kesesuaian Isi \\ Kelengkapan Materi}

Aspek kelengkapan materi, berdasarkan Tabel 4.1 pada hasil penelitian dan pembahasan terlihat bahwa pada subaspek ini, buku teks memperoleh skor 99,94 dengan tingkat kualitas Sangat Baik. Dalam subaspek ini ada tiga indikator, yaitu materi-materi yang mengandung $\mathrm{KI}$ dan $\mathrm{KD}$, materi memuat aspek ranah kognitif, psikomotor, dan afektif (sikap), serta materi memuat pembelajaran dengan pendekatan scientific (ilmiah) seperti mengamati, menanya, menalar, mencoba, dan membentuk jejaring.

Secara umum, materi-materi yang disajikan dalam buku teks Bahasa Indonesia SMP kelas VIII terbitan Kemendikbud edisi revisi tahun 2017, untuk indikator 1a sudah mengandung Kompetensi Inti (KI) dan Kompetensi Dasar (KD) sesuai dengan yang ada dalam silabus. Urutan materi disajikan terdiri atas bab 1 sampai dengan 9. Masingmasing bab menggunakan urutan pengkodean urutan KI dengan huruf A, B, C, D. Kode A dan $\mathrm{C}$ memuat materi KI 3 yang di dalamnya mengandung KD 3.1 sampai dengan KD 3.18. 
Sedangkan kode B dan D memuat materi KI 4 yang di dalamnya mengandung KD 4.1 sampai dengan KD 4.18. Kekurangan yang ditemukan, walaupun tidak mempengaruhi skor, yaitu dalam buku teks tidak menyertakan KD yang akan dibahas pada setiap bab yang disajikan (tersirat). Jadi, dalam hal ini guru harus inisiatif sendiri untuk menyampaikan KD yang akan dibahas kepada peserta didik. Selengkapnya dapat dilihat pada Lampiran 5 halaman 149-173.

\section{Keruntutan Materi}

Aspek selanjutnya yaitu keruntutan materi, buku teks ini memiliki tingkat kualitas yang Sangat Baik dengan skor 100. Secara umum, mulai dari bab 1 sampai dengan bab 9 ditinjau dari urutan KD sudah runtut (tahap demi tahap) yaitu mulai KD 3.1/4.1 sampai dengan KD 3.18/4.18. Materi dalam teks disusun mulai dari kompleksitas sederhana ke yang lebih rumit. Kegiatan-kegiatan dilakukan melalui kaidah-kaidah ilmiah atau pembelajaran saintifik sehingga urutan-urutan kegiatan dimulai dari kegiatan mengamati sampai mengomunikasikan kepada orang lain.

Materi yang disajikan dari bab 1 sampai dengan bab 9 sudah disajikan secara runtut, mulai dari proses melakukan pengamatan dari suatu fenomena untuk menemukan masalah, merumuskan pertanyaan, mencoba mengumpulkan data atau informasi, mengasosiasi/menganalisis data atau informasi untuk menarik kesimpulan, mengomunikasikan kesimpulan, serta mencipta. Pada tahap melakukan pengamatan, dalam buku teks ini disajikan teks bacaan yang terkait dengan fenomena-fenomena yang terjadi untuk diamati oleh peserta didik antara lain disajikan ilustrasi atau cerita. Pada tahap berikutnya peserta didik diajak untuk merumuskan pertanyaan ataupun menjawab pertanyaan yang bersumber pada bahan teks bacaan pada tahap satu sebagai ilustrasi. Tahap ketiga yaitu mengumpulkan data ataupun mengeksplorasi yang bersumber pada teks bacaan ilustrasi pada setiap bab yang dibahas. Selanjutnya peserta didik diajak untuk mengasosiasi/ menganalisis data atau informasi yang bersumber pada teks bacaan yang telah disajikan. Tahap terakhir yaitu peserta didik diajak untuk membentuk jejeraing serta berlatih mengomunikasikan apa yang telah dilakukan pada tahap-tahap sebelumnya. Langkah-langkah tersebut di atas sudah tergambar secara runtut pada setiap subab dalam buku teks sesuai dengan urutan KD dalam silabus.

Secara umum, materi yang disajikan dilihat dari urutan KD sudah runtut, sesuai dengan urutan KD yang ada dalam silabus. Materi sudah menggambarkan langkahlangkah pembelajaran dengan mengacu pada pendekatan saintifik, yaitu mulai dari proses melakukan pengamatan dari suatu fenomena untuk menemukan masalah, merumuskan pertanyaan, mencoba mengumpulkan data atau informasi, mengasosiasi/ menganalisis data atau informasi untuk menarik kesimpulan, mengomunikasikan kesimpulan, serta mencipta. Aktivitas peserta didik sudah tergambar melalui urutan kegiatan-kegiatan yang harus dijalani.

\section{Keterkaitan (Connection)}

Subaspek ketiga adalah materi memunculkan aspek keterkaitan (connection) yaitu memperoleh skor $\mathbf{9 8 , 4 1}$ dengan tingkat kualitas Sangat Baik. Indikator pertama adalah materi memuat hubungan antar konsep Bahasa Indonesia dengan ilmu lain. Keterkaitan yang muncul antara lain dengan ilmu sosial/kemasyarakatan/ budaya, geografi, teknologi, pendidikan, kewarganegaraan, perniagaan, biologi, sejarah, seni/sastra, kesehatan, alam, dan sebagainya.

\section{Penyajian Konsep dilengkapi dengan Gambar, Tabel, Skema, atau Ilustrasi}

Subaspek keempat yaitu penyajian konsep dilengkapi dengan gambar, tabel, skema, atau ilustrasi. Subaspek ini memperoleh skor $\mathbf{1 0 0}$ dengan tingkat kualitas Sangat Baik. Subaspek ini terdiri atas dua indikator yaitu a) penyampaian memenfaat cerita atau ilustrasi, gambar, tabel, skema, atau grafik; b) penyampaian menjelaskan keterkaitan antara konsep dengan dengan cerita atau ilustrasi, gambar, tabel, skema, atau grafik. Secara umum, untuk memancing peserta didik berpikir kritis dan kreatif, serta untuk lebih memperjelas konsep, dalam buku 
ini sudah dilengkapi dengan cerita atau ilustrasi, gambar, tabel, skema, ataupun grafik.

Dari beberapa subaspek pada variabel isi ini diperoleh skor rata-rata 99,34 dengan tingkat kualitas Sangat Baik. Walapun demikian ada beberapa bagian yang perlu pembenahan dan perbaikan terutama yang terkait dengan subaspek-subaspek tersebut.

\section{Aspek Kesesuaian Pembentukan Karakter}

Aspek kesesuaian pembentukan karakter ini terdiri dari lima nilai karakter yaitu 1) Religius; 2) Nasionalisme; 3) Kemandirian; 4) Gotong Royong; 5) Integritas. Berdasarkan hasil analisis, karakter Religius memperoleh skor 93,65 dengan tingkat kualitas Sangat Baik. Karakter Nasionalisme memperoleh skor 80,95 dengan tingkat kualitas Baik. Karakter Kemandirian memperoleh skor 93,65 dengan tingkat kualitas Sangat Baik. Karakter Gotong Royong memperoleh skor 96,83 dengan tingkat kualitas Sangat Baik. Karakter Integritas memperoleh skor 96,83 dengan tingkat kualitas Sangat Baik. Dari lima subaspek pada variabel kesesuaian pembentukan karakter ini diperoleh skor ratarata 94,92 dengan tingkat kualitas Sangat Baik.

\section{Aspek Kesesuaian Kompetensi Abad 21 (4Cs)}

Aspek kesesuaian Kompetensi Abad 21 (4Cs) ini terdiri dari empat kompetensi. Kompetensi pertama yaitu Ceativity Thinking and Innovation dengan indikator: a) Berpikir secara kreatif; b) Bekerja kreatif dengan lainnya; c) Mengimplementasikan inovasi. Kompetensi kedua yaitu Critical Thinking and Problem Solving dengan indikator: a) Penalaran efektif; b) Menggunakan sistem berpikir; c) Membuat penilaian dan keputusan; d) Memecahkan masalah. Kompetensi ketiga yaitu Communication dengan indikator: berkomunikasi secara jelas. Kompetensi keempat yaitu Collaboration dengan indikator: berkolaborasi dengan orang lain.

Kompetensi Ceativity Thinking and Innovation memperoleh skor $\mathbf{9 6 , 8 3}$ dengan tingkat kualitas Sangat Baik. Kompetensi Critical Thinking and Problem Solving memperoleh skor 99,21 dengan tingkat kualitas Sangat Baik. Kompetensi Communication memperoleh skor $\mathbf{9 3 , 6 5}$ dengan tingkat kualitas Sangat Baik. Kompetensi Collaboration memperoleh skor 93,65 dengan tingkat kualitas Sangat Baik. Perolehan skor rata-rata keseluruhan adalah 95,83 dengan tingkat kualitas Sangat Baik.

Dari pembahasan yang telah dipaparkan di atas yang terdiri dari tiga aspek yaitu aspek kesesuaian isi memperoleh skor rata-rata sebesar 99,34, aspek kesesuaian pembentukan karakter memperoleh skor 92,38, dan aspek kesesuaian Kompetensi Abad 21 (4Cs) memperoleh skor $\mathbf{9 5 , 8 3}$, maka rata-rata skor keseluruhan aspek sebesar 95,85 dengan tingkat kualitas Sangat Baik. Dengan demikian dapat disimpulkan bahwa buku teks Bahasa Indonesia SMP Kelas VIII terbitan Kemendikbud edisi revisi tahun 2017 sangat layak digunakan sebagai buku teks wajib untuk proses pembelajaran.

\section{KESIMPULAN}

Berdasarkan hasil pembahasan dalam penelitian ini, peneliti membuat beberapa simpulan sebagai berikut: 1) Kesesuaian isi buku teks Bahasa Indonesia SMP kelas VIII terbitan Kemendikbud edisi revisi tahun 2017. Subaspek pertama kelengkapan materi, memperoleh skor 98,94 dengan tingkat kualitas Sangat Baik. Subaspek kedua yaitu keruntutan materi, memperoleh skor 100 dengan tingkat kualitas Sangat Baik. Subaspek ketiga yaitu materi memunculkan aspek keterkaitan (connection) memperoleh skor 98,41 dengan tingkat kualitas Sangat Baik. Subaspek keempat yaitu penyajian konsep dilengkapi dengan gambar, tabel, skema, atau ilustrasi, memperoleh skor 100 dengan tingkat kualitas Sangat Baik. Skor rata-rata untuk aspek kesesuaian isi sebesar 99,34 dengan tingkat kualitas Sangat Baik. 2) Kesesuaian pembentukan karakter buku teks Bahasa Indonesia SMP kelas VIII terbitan Kemendikbud edisi revisi tahun 2017. Subaspek pertama yaitu religius, memperoleh skor 93,65 dengan tingkat kualitas Sangat Baik. Subaspek kedua yaitu nasionalisme, memperoleh skor 80,95 dengan tingkat kualitas Baik. Subaspek ketiga yaitu 
kemandirian, memperoleh skor 93,65 dengan tingkat kualitas Sangat Baik. Subaspek keempat yaitu gotong royon, memperoleh skor 96,83 dengan tingkat kualitas Sangat Baik. Subaspek kelima yaitu integritas, memperoleh skor 96,83 dengan tingkat kualitas Sangat Baik. Skor rata-rata aspek kesesuaian pembentukan karakter sebesar 92,38 dengan tingkat kualitas Sangat Baik. 3) Kesesuaian Kompetensi Abad 21 (4Cs) buku teks Bahasa Indonesia SMP kelas VIII terbitan Kemendikbud edisi revisi tahun 2017. Subaspek pertama yaitu Creatifity Thinking and Innovation atau berpikir kreatif dan inovasi, memperoleh skor 96,83 dengan tingkat kualitas Sangat Baik. Subaspek kedua yaitu Critical Thinking and Problem Solving atau penalaran efektif dan memecahkan masalah, memperoleh skor 99,21 dengan tingkat kualitas Sangat Baik. Subaspek ketiga yaitu Communication atau komunikasi, memperoleh skor 93,65 dengan tingkat kualitas Sangat Baik. Subaspek keempat yaitu Collaboration atau kolaborasi, memperoleh skor 93,65 dengan tingkat kualitas Sangat Baik. Skor rata-rata aspek kesesuaian Kompetensi Abad 21 (4Cs) sebesar 95,83 dengan tingkat kualitas sangat baik.

Berdasarkan hasil penelitian tersebut, buku teks Bahasa Indonesia SMP kelas VIII terbitan Kemendikbud edisi revisi tahun 2017 ini sudah layak untuk digunakan sebagai bahan ajar atau buku wajib pada mata pelajaran Bahasa Indonesia kelas VIII jenjang SMP/MTs.

\section{DAFTAR PUSTAKA}

Arikunto, Suharsimi. 2006. Prosedur Penelitian Suatu Pendekatan Praktik, edisi revisi VI, cet. 13. Jakarta: PT Rineka Cipta.

Ariyana, Yoki. dkk. 2019. Buku Pegangan Pembelajaran Berorientasi pada Keterampilan Berpikir Tingkat Tinggi. Jakarta: Dirjen GTK Kemendikbud.

Badan Standar Nasional Pendidikan, 2006. Standar Isi untuk Satuan Pendidikan Dasar dan Menengah. Jakarta: Badan Standar Nasional Pendidikan.
Bungin, Burhan. Analisis Data Penelitian Kualitatif. Jakarta: Raja Grafindo Persada.

Departemen Pendidikan Nasional. 2005. Peraturan Menteri Pendidikan Nasional Nomor 11 Tahun 2005 tentang Buku Teks Pelajaran. Jakarta: Departemen Pendidikan Nasional.

Departemen Pendidikan Nasional. 2007. Peraturan Menteri Pendidikan Nasional Nomor 22 Tahun 2007 tentang Penetapan Buku Teks Pelajaran yang Memenuhi Syarat Kelayakan. Jakarta: Departemen Pendidikan Nasional.

Departemen Pendidikan Nasional. 2007. Peraturan Menteri Pendidikan Nasional Nomor 46 Tahun 2007 tentang Penetapan Buku Teks Pelajaran yang Memenuhi Syarat Kelayakan untuk Digunakan dalam Proses Pembelajaran. Jakarta: Departemen Pendidikan Nasional.

Departemen Pendidikan Nasional. 2013. Peraturan Menteri Pendidikan Nasional Nomor 71 Tahun 2013 tentang Penetapan Buku Teks Pelajaran yang Memenuhi Syarat Kelayakan untuk Digunakan dalam Proses Pembelajaran. Jakarta: Departemen Pendidikan Nasional.

Heryadi, Dedi. 2010. Metode Penelitian Pendidikan Bahasa. Bandung: Pustaka Billah.

Kementerian Pendidikan dan Kebudayaan Republik Indonesia, edisi revisi. 2017. Bahasa Indonesia SMP/MTs Kelas VIII. Jakarta: Kementerian Pendidikan dan Kebudayaan.

Margono. 2009. Metodologi Penelitian Pendidikan. Jakarta: Rineka Cipta.

Moleong, Lexy. 2005. Metodologi Penelitian Kualitatif. Bandung: Remaja Rosdakarya. 
Muljono, Pudji. 2007. Kegiatan Penilaian Buku Teks Pelajaran Pendidikan Dasar dan Menengah. Dalam Buletin BSNP Vol II/ No. 1/Halaman 23.

Muslich, Masnur. 2010. Textbook Writing, Dasar-Dasar Pemahaman, Penulisan, dan Pemakaian Buku Teks. Yogyakarta: Ar-Ruzz Media.

Prastowo, Andi. 2014. Panduan Kreatif Membuat Bahan Ajar Inovatif. Yogyakarta: Diva Press.

Pusat Perbukuan. 2005. Pedoman Penilaian Buku Bahasa Indonesia untuk Sekolah Menengah Pertama dan Sekolah Menengah Atas. Jakarta. Departemen Pendidikan Nasional. Pusat Bahasa. 2008. Kamaus Bahasa Indonesia. Jakarta: Departemen Pendidikan Nasional.

Rachim, Fathur. 2019. How To STEAM Your Classroom Revo 4.0 Model-Outside
The Boxx (Part-1). Jakarta: Agtifindo.

Sugiyono. 2018. Metode Penelitian Kuantitatif, Kualitatif dan $R \& D$. Bandung: Alfabeta.

Suwartono, 2014. Dasar-Dasar Metodologi Penelitian. Yogyakarta. Andi Offset.

Tarigan, Henry Guntur dan Djago Tarigan. 2009. Telaah Buku Teks Bahasa Indonesia. Bandung. Angkasa.

Tim Pengembang Pedoman Bahasa Indonesia. 2016. Pedoman Umum Ejaan Bahasa Indonesia. Jakarta: Badan Pengembang dan Pembinaan Bahasa Indonesia, Kementerian Pendidikan dan Kebudayaan.

Uno, H. 2006. Perencanaan Pembelajaran. Jakarta: Bumi

Aksara 